\title{
IMPACT OF THE PANDEMIC COVID-19 TO THE INDONESIA SEAS
}

\author{
Yudi N. IHSAN* \\ Universitas Padjadjaran, Faculty of Fisheries and Marine Sciences, Indonesia, e-mail: yudi.ihsan@unpad.ac.id \\ Noir P. PURBA \\ Universitas Padjadjaran, Research Center for Conservation and Management of Maritime Areas, Indonesia, e-mail: noir.purba@unpad.ac.id \\ Ibnu FAIZAL
}

Universitas Padjadjaran, Research Center for Conservation and Management of Maritime Areas, Indonesia, e-mail: ibnu.faizal@unpad.ac.id

Agnes ANYA

Agence France-Presse, Information Technology \& Services Industry Department, Indonesia, e-mail: anyesanya@gmail.com

Putri G. MULYANI

Universitas Padjadjaran, Marine Research Laboratory (MEAL), Indonesia, e-mail: pugita11@ gmail.com

Sarah K. ANWAR

MOCEAN Institute, Research and Development Department, Indonesia, e-mail: sarah.khairunnisa99@ gmail.com

\begin{abstract}
Citation: Ihsan, Y.N., Purba, N.P., Faizal, I., Anya, A., Mulyani, P.G., \& Anwar, S.K. (2022). IMPACT OF THE PANDEMIC COVID-19 TO THE INDONESIA SEAS. GeoJournal of Tourism and Geosites, 40(1), 30-36. https://doi.org/10.30892/gtg.40103-799
\end{abstract}

\begin{abstract}
This paper presents the effect of the COVID-19 pandemic on the Indonesian seas from April to October 2020. Data were mainly obtained through literature studies focusing on coastal and ecosystem services, noise observation in the ocean, and in-situ data for atmospheric conditions. The results of this study found that the pandemic has given the oceans and ecosystems time to recover from anthropogenic stresses even though the tourism and fisheries sectors have experienced strong economic shocks. A decrease in the amount of pollution in several major cities in Indonesia was also found during the pandemic period.
\end{abstract}

Key words: ocean-atmosphere interaction, ocean health, marine pollution, pandemic COVID-19, carbon

\section{INTRODUCTION}

The coronavirus (COVID-19) has become the largest pandemic in 21 centuries. It becomes a lasting history to humankind due to its effect on daily life (Bates et al., 2021; Canning-Clode et al., 2020). Until now, this pandemic is still rising and affecting global countries and territories around the world. Since the World Health Organization (WHO) declared the coronavirus pandemic on March 11, 2020, there have been significant decreases in human activities. Most countries around the world went into lockdown to reduce the spread of COVID-19. Several studies showed that the coronavirus pandemic is expected to end in December 2020 (Zuhairoh and Rosadi, 2020). However, until July 2021, we are still facing this issue with a new more contagious variant. Global leaders believe that vaccine is the best way to build herd immunity. In the world, only about $25 \%$ of people who have received one vaccine (Ritchie et al., 2020). Meanwhile, in Indonesia, no more than 10\% of people have been vaccinated. As an archipelagic country, almost 34 provinces in Indonesia are affected by covid-19. It is difficult to see how this problem may be solved with plenty of various cultures, regulations, and pandemic levels.

This COVID-19 has been of interest not only to health researchers but also environmental scientists. Theoretically, with the reduction of human activities, natural environmental improvements are expected. This reduction in activity is interpreted as a slowdown in everyday human activities (mobility), also known as "anthro-pause" or great pause (Rutz et al., 2020). With this pandemic situation, it is believed that environmental impacts will be reduced. As we all know, human actions cause environmental devastation (Partelow et al., 2015), including destructions of the largest biota (Gaynor et al., 2018), and ecosystem including coral bleaching (Gusviga et al., 2021) (Figure 1). This study summarizes the condition of the marine environment before, during the pandemic and future predictions of Indonesia territories. Since humans limit their activities at sea, the reduction or absence of anthropogenic conflicts may also promote an ideal opportunity for studies on marine wildlife behaviour and ecology (Bates et al., 2020). Understanding the connections between human activities and interactions with the ocean is critical (Bates et al., 2021). Several studies on the impact of the pandemic on marine environments have previously been conducted. The pandemic appears to offer hope for better ocean health (Zambrano-Monserrate et al., 2020). The worldwide response concerning the COVID-19 pandemic has led to a rapid reduction of air pollutants, especially in big cities (Forster et al., 2020). Before the pandemic, the Indonesian Ocean Health Index (OHI) had a score of 65 with a rank of 137 out of 221 countries (Halpern et al., 2012), one of which

\footnotetext{
* Corresponding author
} 
includes marine pollution. The absence of human influence in the seas during the pandemic allows the ecosystems and nature to recover. Furthermore, an overview of the current situation and predicted implications for biodiversity conservation has been provided, emphasizing that it is premature to predict the overall impacts in the field (Corlett et al., 2020). This paper will focus on several aspects, i.e., i) coastal and ecosystem services, ii) noise observation in the ocean and its relationship to the presence of biota, iii) carbon systems and ocean acidification, and iv) future challenges.

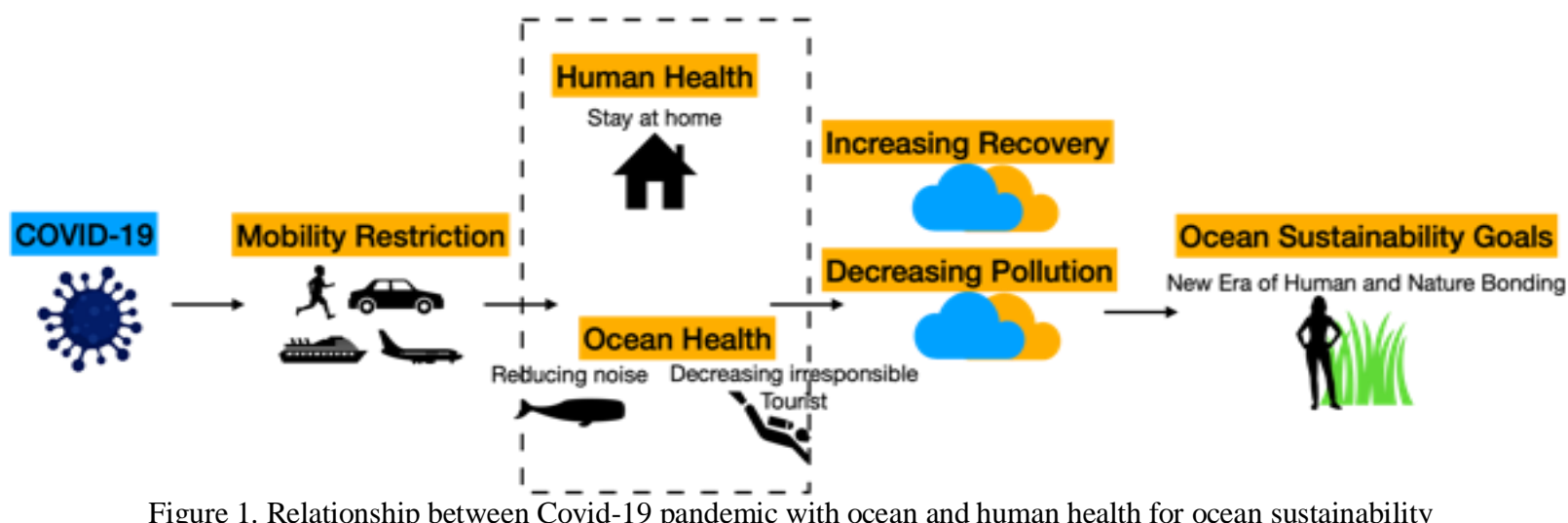

\section{MATERIALS AND METHODS}

In the literature review process (Knopf, 2006), we followed a systematic approach in selecting papers with keywords "COVID-19, OCEAN, MARINE". First, we searched those keywords in Publish or Perish software from 2020 to 2021 and obtained 964 results. Afterwards, we manually selected papers that were most relevant to our topic. This step led to a total number of 123 articles. They were reviewed individually for analysis. Secondly, we conducted online group discussions with experts from NGOs, marine stakeholders, marine staff, and academic experts. The participants came from different regions in Indonesia to find out the effect of the pandemic in various locations. We also communicate by phone and email to several marine/environmental experts. Eventually, we discussed in online seminars on national and international levels specific to ocean and covid-19. There was a total of 64 online conferences and workshops from April to October 2020. To support this research, we also used OFFL data to analyze $\mathrm{CO}$ and $\mathrm{NO}_{2}$ levels from November 2019 to December 2020 (Omrani et al., 2020). The downloaded image data were obtained from the satellite Sentinel-5P.

The presented data consists of two options, i.e. Offline data (OFFL) and Near Real-Time (NRTI) data. $\mathrm{CO}$ and $\mathrm{NO}_{2}$ data levels in Indonesia are satellite image data from Sentinel-5P. Data retrieval is done by downloading image data through a cloud-based computing device, i.e. Google Earth Engine (GEE). The analysis was done by comparing the opinions of the presenters, reports, conducting a literature analysis, and from primary data.

\section{RESULTS AND DISCUSSION}

\section{Coastal and Ecosystem Services}

Beaches and coastal areas are among the most important natural capital assets (Yang et al., 2021). In most locations in Indonesia, they provide services that are critical to the survival of coastal communities and possess core values. However, irresponsible people have caused many destruction and pollution (Garcés-Ordóñez et al., 2020). For example, snorkelling and diving activities are examples of tourists' activities at sea and interact directly with ecosystems and mainly caused damage to its area (Nyström et al., 2000). Despite the fact that the number of visitors to the beach is increasing, the infrastructures are inadequate, and people's habits harm the surrounding habitats and ecosystems.

During the pandemic, the decreasing number of tourists has caused a notable change in the appearance of numerous beaches in Indonesia, such as Kuta beach in Bali, Gili, Lombok, and various islands in Pulau Seribu, Jakarta. Local authorities at the time closed frequented locations to avoid crowds. The same condition also happened to beaches in Acapulco (Mexico), Barcelona (Spain), and Salinas (Ecuador), where they all look cleaner with crystal clear waters (Zambrano-Monserrate et al., 2020). Furthermore, several discussions with a member of the Indonesia Recreational Diving Business Association (PUWSI) reported that in April 2020, 26 businesses experienced a decrease in the number of visitors in their operational areas. Almost all tourist areas are closed from April to August 2020.

However, in a global context, many beaches are still polluted in other cases due to anthropogenic debris from terrestrial areas (Patrício Silva et al., 2021). Furthermore, on several beaches in Indonesia, there was a rise of Personal Protective Equipment (PPE) waste in rivers and beaches in Jakarta bay (Cordova et al., 2020). This is especially the case in island areas such as Seribu Islands in Jakarta. This case due to pandemic events result in the emergence of garbage coming from hospitals. But cases like this are not found on Pangandaraan beach or Pelabuhan Ratu. This is due to the river's mouth in these two regions is not as much as DKI Jakarta, which has 12 river estuaries. Another report also stated that the pandemic causes negative impacts on the ecosystem by $17 \%$. This is seen in some areas of illegal fishing and destructive fishing. The decline in diving tourism activities affects the rise of illegal fishing in the surrounding waters, including the national park area. Destructive fishing is increasing due to the absence of activities/routines at diving sites. Illegal fishing occurs as there is no tourism activity in the area, causing tourism workers to carry out other jobs, catching ornamental fish. A report and communication with the RARE Indonesia agency conducted questionnaires to small fishers in Kepulauan Seribu and 
around Southeast Sulawesi stated that small fishers experienced a decrease in the activity restrictions demand, which decreased their fishing frequency and reduced fish prices. However, their daily needs can still be fulfilled from the sea. However, there was an increased income in some regions, such as the Maluku islands and North Maluku.

In an example of the recovery case, Thailand's Department of National Parks has announced the closure extension of the Maya Bay coastal area so that damaged coral reefs can heal and recover. The beach is closed to allow the ecosystem and biota to recover, accompanied by human care. Humans do limit themselves to activities in nature during the pandemic, but there is no treatment for nature like what is done in Thailand. Gili-Lombok (Archie-Personal communication) stated that the number of visitors dropped dramatically to $90 \%$, and more biota like manta rays were found around the reef. However, marine debris is still widely found because it comes from anthropogenic waste. Furthermore, almost all tourist areas experience a decrease in the number of tourists due to the rules of the local government to close tourist locations.

Several seminars on pandemics and ocean services discovered that the pandemic gave coral reefs time to recover. This occurs in various places like Raja Ampat and numerous diving sites in Papua waters. There are also improvements in ecosystems of the conservation waters of Savu, East Nusa Tenggara. Prior to the coronavirus pandemic, ecosystems, especially coral reefs, directly impacted marine tourism activities such as physical contact when tourists dive or snorkeling. These disturbances cumulatively contribute to suppressing coral reefs (Shokri and Mohammadi, 2021). Recently, there has been no scientific monitoring due to a lack of funding and data before the pandemic.

\section{Noise in The Ocean}

The pandemic hit several shipping industries. However, most of the effects have yet to be measured. The decreased activity in the Indonesian fishing sector that catches fish is around $30-40 \%$ (Indonesian Tuna), China and Africa 80\%. Before Covid-19, shipping lines around Anambas Island and the South China Seas (SCS) were crowded with large vessels carrying goods, survey ships, and fishing. During Covid19 , the pathway experienced a very significant decrease in density (Figure 2). Based on the analysis of vessels activities and types of gears (including drifting longlines and nets, purse seines and trawlers), ocean fishing is reduced by $12 \%$ (Bates et al., 2021).

However, based on a recent publication, the shipping activities around Indonesia increased in April 2020 (March et al., 2021). This may occur since there are three international routes in the Indonesian waters. There was a vast reduction of fishing vessels. From reports and discussions with stakeholders, it is seen clearly in several Indonesian waters, such as the Java Sea, South China Sea, and northern Sulawesi. The decrease
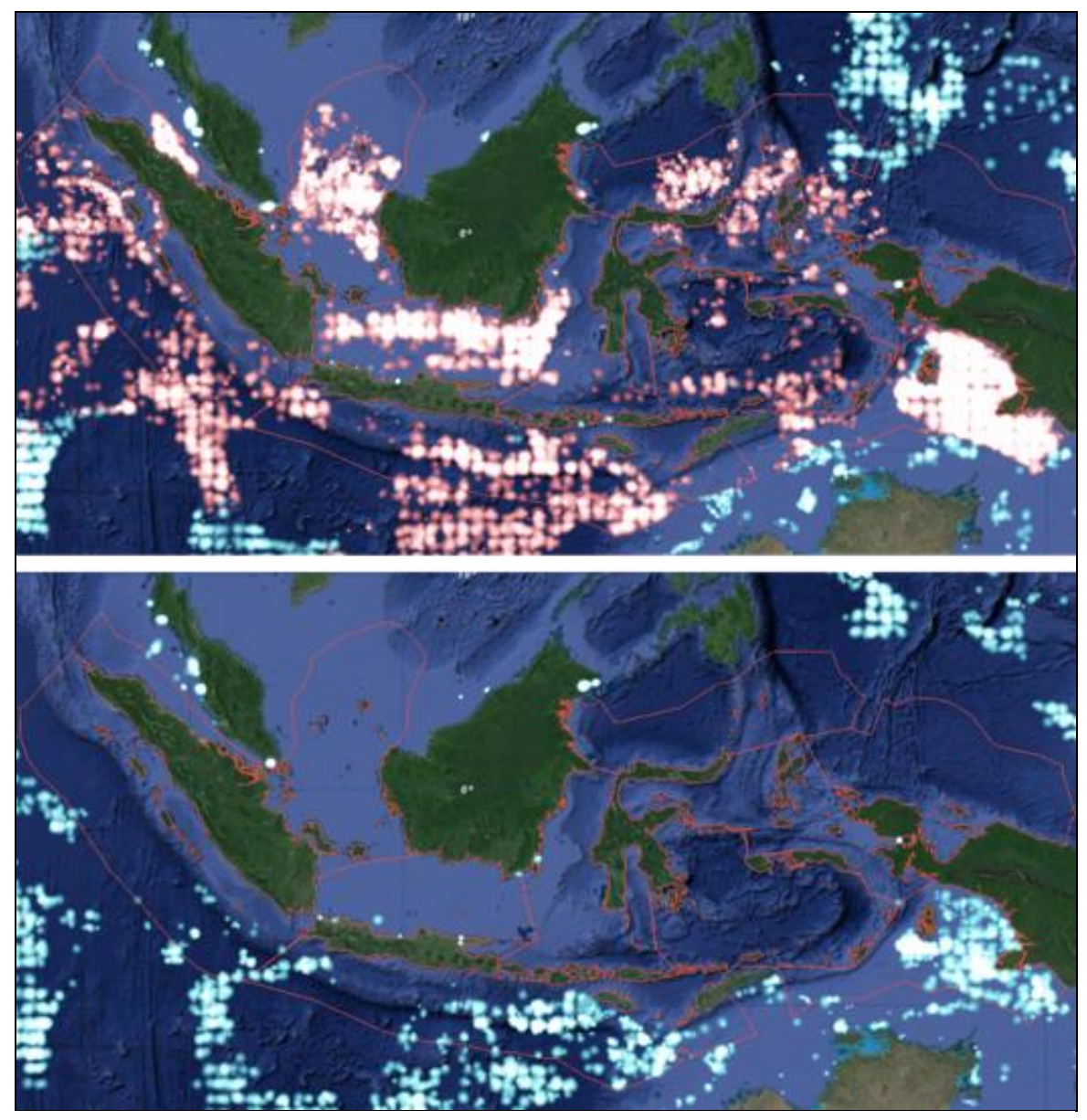

Figure 2. Snapshot of vessel activities around Indonesia seas with night light vessel detections (orange dots) and VMS (Vessel Monitoring System; blue dots).

The top figure represents July to December 2019, and the bottom illustrates

July to December 2020 (Source from https://globalfishingwatch.org/map )

was also caused by the reduced demand for fish exports from Indonesia. Previous research had also suggested that export demand from Australia to other countries was decreased during the pandemic (Plagányi et al., 2021). In the ocean, noise could be generated by water column dynamics and human activities such as ship engines (Erbe et al., 2020). Naturally, marine biota can tolerate noise from water columns. However, this kind of noise is one of the primary sources of disturbance for the biota and the environment, altering the natural conditions of the shallow ecosystems and causing health problems (Zambrano-Monserrate and Ruano, 2019). Due to propagation, the sound is much faster in the ocean than in the air (4:1). It means that the range of a single sound source is much broader, and its effect can be worse than we initially thought. The forms of disturbances that occur due to sound varies, depending on the type of marine life.

The most suitable marine biota to be studied for this theme is animals that use high decibel sounds to communicate, one of which is whales.As humans retreat, animals quickly move in to fill the empty spaces (Bates et al., 2021). Based on a 
discussion with experts in Indonesia, an interesting rare phenomenon of Orca whales was seen on Anambas Island. This phenomenon may have been related to the drastic decrease in shipping activities in the South China Sea, including exploration vessels firing high-decibel signals into the ocean. Meanwhile, people in Papua have reported the emergence of large numbers of fish in previously absent areas due to ship noises. But this case does not occur in all places, for example, in the waters of the Strait of Malacca, which also experienced a reduction in shipping lanes found no appearance of biota. Of the three international routes that pass through Indonesia (ALKI), the discovery of biota was found on one path only.

\section{Atmospheric Pollution Trend}

Before 2020, $\mathrm{CO}_{2}$ emissions rose about $1 \%$ per year over the previous decade (Zhang et al., 2017). The rest of the world is expected to grow by +0.5 per cent in 2019. A change habit in the land and ocean carbon sink behaviour will take the same amount of time to detect and much longer if it emerges slowly (Friedlingstein et al., 2019). Based on previous researches, carbon emissions dropped by 17\% in early April 2020 (Le Quéré et al., 2020). The highest contributing factor which decreases emissions come from surface transportations. In a global context, about $5 \%$ of emissions returned rapidly in June (1\%-8\% range) (WMO, 2020). In 2020, several countries had reported improvements in air quality. Research in Korea found that air pollution dropped by $45.45 \%$ following the COVID-19 restriction (Ju et al., 2021). Meanwhile, air pollution $\left(\mathrm{NO}_{2}\right)$ declined by $51 \%$ (Tobías et al., 2020). The decrease in air pollution also occurs in New York (Zangari et al., 2020).

During the COVID-19 restrictions in Indonesia, air quality in crowded cities such as Jakarta and Semarang improved due to reduced human activities in industries and transportations. Densely populated provinces started to impose mobility restrictions in early April, and since then, the measures have been on-off depending on local authorities' evaluation of the COVID-19 situation. However, Indonesia's Meteorology, Climatology and Geophysics Agency (BMKG) has few changes in other regions. These cities already have relatively clean air quality. The results of image data on carbon monoxide (CO) and nitrogen dioxide $\left(\mathrm{NO}_{2}\right)$ from the Sentinel-5P satellite in Indonesia's territories were visualized. They showed pixel points of different colours in each area at a certain period. The visualization depicts $\mathrm{CO}$ and $\mathrm{NO}_{2}$ content in the air from November 2019 - December 2020. The pixel dots of various colours represent $\mathrm{CO}$ and $\mathrm{NO}_{2}$ concentrations; red indicates high pollution. The lighter the colour (or towards yellow, green, then blue), the lower the $\mathrm{CO}$ and $\mathrm{NO}_{2}$ concentrations in the area. The $\mathrm{CO}$ concentration values ranged from $0.02-0.05 \mathrm{~mol} / \mathrm{m}^{2}$ and the $\mathrm{NO}_{2}$ concentration values ranged from $3 \times 10^{-5}-6 \times 10^{-5} \mathrm{~mol} / \mathrm{m}^{2}$.

The visualization results of Indonesia's carbon monoxide (CO) content show that $\mathrm{CO}$ concentrations tended to be high in November 2019. The high CO concentrations in November 2019 were concentrated in the western part of Indonesia, especially in Jakarta, South Sumatra and a little part of Central Kalimantan. In the same period, the CO concentration level is low in the eastern part of Indonesia, i.e. Papua. It is indicated by the visualization results in yellow and blue. From December 2019 to April 2020, the CO content has begun decreasing, characterized by the visualization results that appear yellow and blue with no red areas. In the western region, the $\mathrm{CO}$ was still concentrating the eastern part of Indonesia, according to the CO concentration in November 2019. The CO concentration decreased from May to December 2020. Overall, the Indonesian regions have relatively low $\mathrm{CO}$ concentrations. In this period, the visualization is dominated by blue colour, although there is still a bright yellow colour cantered around Java island, especially Jakarta. There is no specific pattern in the visualization of $\mathrm{CO}$ concentrations in Indonesia in each period. However, there is a very significant change from November 2019 to December 2020, which is noticeable from November 2019 until January 2020.

The visualization results of nitrogen dioxide $\left(\mathrm{NO}_{2}\right)$ in Indonesia show that the $\mathrm{NO}_{2}$ concentrations tend to be high in western Indonesia during November 2019 - December 2020. High levels of $\mathrm{NO}_{2}$ concentrations were concentrated along the Java island, especially in the west of Indonesia and the Malacca Straits. In contrast, in other parts of Indonesia, the $\mathrm{NO}_{2}$ concentration level was relatively low throughout the same period, indicated by the visualization results in yellow and blue. There are significant changes in the concentration of $\mathrm{NO}_{2}$ content between December 2019 to March 2020, especially in areas along Java island. The level of $\mathrm{NO}_{2}$ content was initially very high in the region, then began to decrease (marked by a colour change from red to yellow). After March 2020, $\mathrm{NO}_{2}$ in Java Island increased again, but the coverage area with high $\mathrm{NO}_{2}$ was not as vast as in November 2019. On the contrary, high $\mathrm{NO}_{2}$ concentrations in the Malacca Strait region increased from March 2020 to May 2020, marked by an expansion of the red area. The western part of Indonesia outside of Java and the Malacca Strait also experienced an increase in $\mathrm{NO}_{2}$ content, seen from the change of blue to yellow. Other regions in Indonesia (central to eastern) appear stable and have a relatively low $\mathrm{NO}_{2}$ range, but an increase is still visible, especially from March to May 2020. Overall, the visualization of $\mathrm{NO}_{2}$ concentration does not show any significant changes when compared to $\mathrm{CO}$.

Indonesia's Meteorology, Climatology and Geophysics Agency (BMKG) https://www.bmkg.go.id/kualitasudara/informasi-partikulat-pm10.bmkg measured on PM10 concentrations in 8 locations from September to October 2020. The locations were Indrapuri, Kemayoran, Pontianak, Cibeureum, Medan, Pangkalanbun, Pekanbaru Kota and Sidoarjo. The results showed that the PM10 concentrations in September were still below the threshold $\left(<150 \mu \mathrm{g} / \mathrm{m}^{3}\right)$. Meanwhile, on October 1, the highest daily average concentration of PM10 was $73.21 \mu \mathrm{g} / \mathrm{m}^{3}$ in Kemayoran on October 1, 2020. The lowest level was in Pekanbaru Kota on October 3, 2020 at $5.27 \mu \mathrm{g} / \mathrm{m}^{3}$. October's highest PM10 level was lower than in September $\left(99.35 \mu \mathrm{g} / \mathrm{m}^{3}\right)$, also found in Kemayoran. Based on observations in the second and third September and the first ten days of October 2020, there are fluctuating levels of PM10 concentration in Kemayoran. Kemayoran once experienced a maximum hourly value of $>200 \mu \mathrm{g} / \mathrm{m}^{3}$. In general, the average PM10 concentration was still in the range of 50-100 $\mu \mathrm{g} / \mathrm{m}^{3}$, which were considered in good to moderate levels. The air quality improvements had also positively affected corals in waters near tourist sites in Raja Ampat, Papua. Based on the report, damaged corals in the area had been gradually recovering since tourism was halted in line with the restrictions. The damaged corals had started to grow and shown signs of suitable condition, such as new coral polyps appearing with healthy colours. 


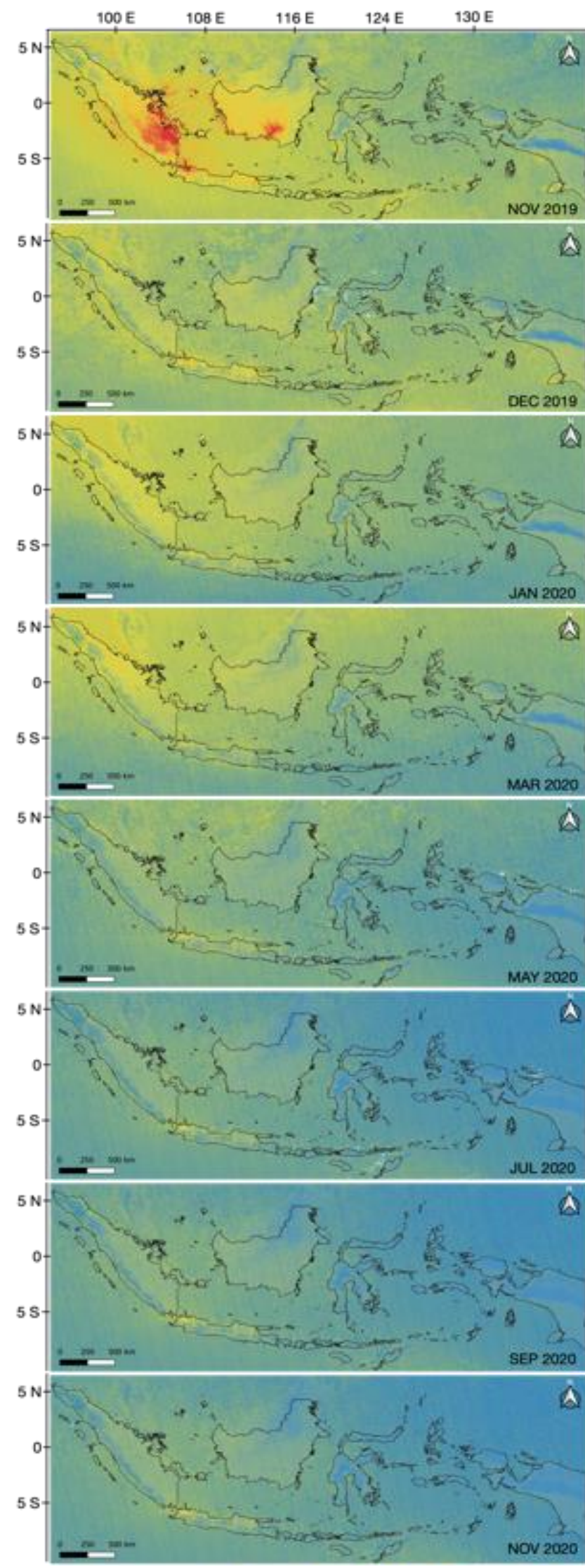

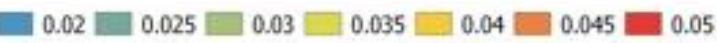
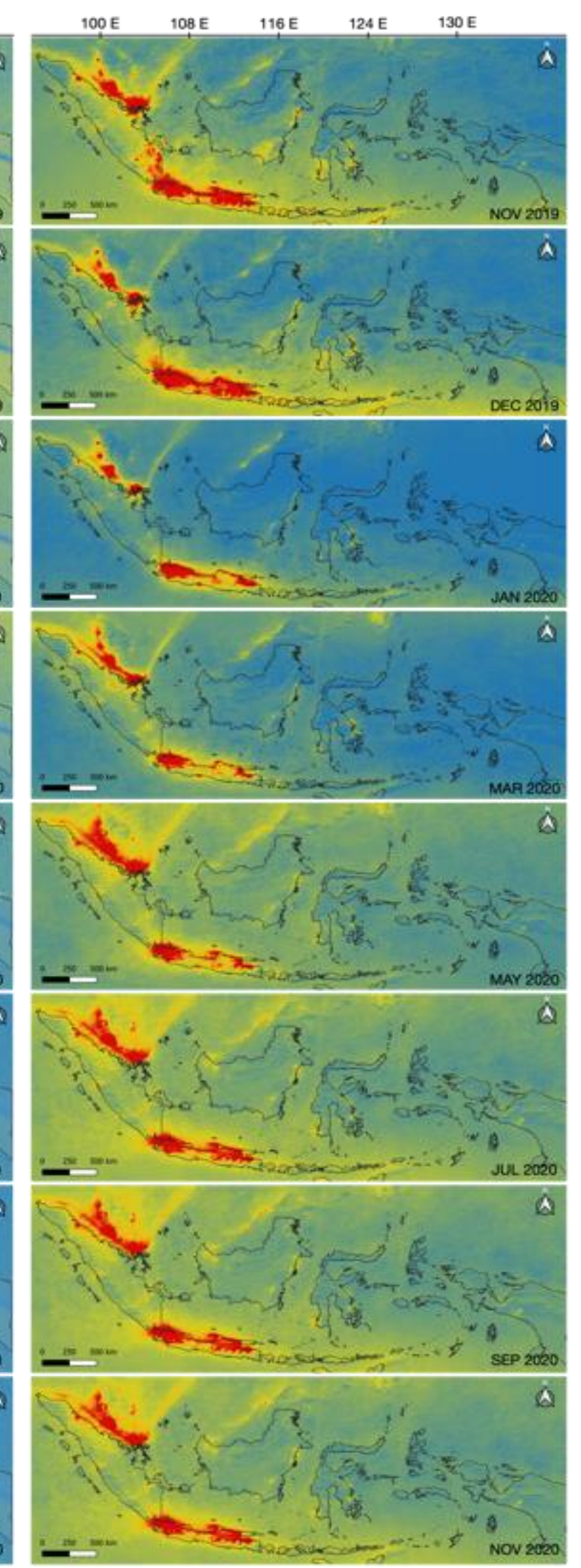

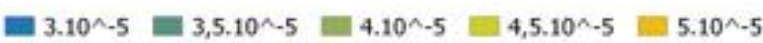

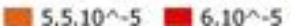

Figure 3. Carbon monoxide concentration (left) and Nitrogen monoxide concentration (right) in $\mathrm{mol} / \mathrm{m}^{2}$ over Indonesia area (Source: Sentinel-5P Satellite $\mathrm{CO}$ and $\mathrm{NO}_{2}$ Imagery Data)

This improvement, however, might be attributed to lower carbon emissions and a considerable reduction in tourist activities. Until July 2021, the COVID-19 pandemic is still ongoing, and there is no certainty when it will end. The word 
"new normal" is still a discourse, but we do not know when it will be implemented due to raising a new coronavirus variant. Meanwhile, the government is still focusing on human recovery activities and fulfilling the vaccine to 250 million people. This resulted in budget cuts in various sectors, especially in the marine sector. By 2020, the ministry of Marine and Fishery Affairs budget will be cut by approximately 1.84 Trillion. The report found that several programs were delayed or cancelled. With many priority programs that are not implemented, monitoring of ecosystems and the sea becomes constrained. This research also found both positive and negative impacts of the pandemic situation on Indonesia's ocean and ecosystem. Overall, reduced human activities on the beach and sea allow time to naturally restore the environment and biota. The decrease in visitor numbers due to the closure of tourist sites has reportedly positively impacted ecosystem restoration. On the other hand, there is also a decrease in the number of marine supervisors in charge of monitoring environmental damage due to human activities. It is not known exactly the percentage of recovery from coastal ecosystems because there is no comprehensive monitoring data. For cases in Indonesia, the application of restrictions on human movement is not the same for each region. This results in beach visits still being allowed in some areas, but elsewhere there is no activity in tourist areas. This also results in different ecosystem recovery for each location.

Then, the reduction in marine noise isn't fully understood yet. The activities of shipping are mainly caused by noise in the Indonesian sea. Although noise is one of the disturbances to marine biota, not many reports mention the emergence of species in some locations that are ship lines. Some reports indicate the appearance of whales and dolphins more often than usual, especially in the dense waters of ship activity. Although further research is still needed, there have been reports of marine species in areas previously populated by human activities. This is a positive impact, and the movement of marine species in Indonesian waters should be studied deeper. As we know, the Indonesian waters are strategic routes for both national and international shipping. Indonesia's territorial waters are also one of the densest areas of fishing activity (Figure 2). The decline in fishing in the sea is due to the decrease in international demand for fish. The same is true of other countries (Plagányi et al., 2021) The resulting impact is the increasing quantity of fish in the ocean, especially in the south of Java, which has been overexploited. Furthermore, there is an improvement in the pollution content in the atmosphere. This can be seen from the decrease in the amount of carbon monoxide in the atmosphere. It is known that atmospheric and ocean interactions result in the continuous transfer of energy and material. $\mathrm{CO}$ is one that results in the acidification of the sea to make coral bleaching occur (Figure 3). The decline occurred mainly in major cities in Java and Sumatra, such as Jakarta, Medan, Surabaya. Both islands have the most densely populated areas in Indonesia.

Overall, it is too early to justify the effect on ocean health due to a lack of data. It is too early to build a conclusion about the systematic impact. Many forum meetings' predictions are mostly based on partial data or existing data. Limited access and time are problems for monitoring at sea (Perillo et al., 2021). Furthermore, monitoring funds are limited due to budget cuts made by the government to prioritize the management of COVID-19. The COVID-19 pandemic directly contributes to the UN 2030 Sustainable Development. The SDGs' achievements and targets are delayed due to the pandemic (including priority programs), especially those related to Goals 13 (Climate Change) and Goals 14 (Life Below Water). Before the pandemic, Indonesia was ranked $137^{\text {th }}$ out of 221 countries. This must be a priority given the reduced monitoring during the pandemic. The use of IoT-based technology must be pursued so that monitoring and observations can be carried out remotely (Purba et al., 2019). This is because Indonesian ecosystems play an essential role in ecosystem connectivity (Salsabilla et al., 2020).

Finally, raising funding in research is urgently required to support the government programme. This includes monitoring programmes, infrastructure, and information system technology (Rutz et al., 2020). The COVID-19 outbreak has indirectly become an opportunity for fishers to revise their mindset and hunting patterns or take from nature for commercial gain. The sustainability principle has been neglected so far, has become a highlight after the rapid spread of information by holding webinars across the country. Globally, reforming marine health policy should be a top priority. New policy decisions will be required, focusing on reconnecting with the environment and, in particular, ocean health (Laffoley et al., 2021). Indonesia, which currently has high marine wealth, is a challenge in and of itself. One issue that needs to be addressed as quickly as possible is the damage to ecosystems caused by global warming (Gusviga et al., 2021).

\section{CONCLUSION}

In general, the covid-19 pandemic has had an enormous impact on Indonesia's oceans. This impact can be seen from three things: the recovery of the shallow ecosystem, noise reduction in the ocean, and pollution reduction in the atmosphere and the sea. Although at this time, the impact cannot be explained comprehensively because of data limitations. Based on this research, a quantitative scientific investigation is urgently required. The fact is that ocean health is intimately tied to human health. Regular monitoring is needed to see changes in the ecosystem. Furthermore, after the normal era, studies on this issue are critical to managing ship routes, especially in the high waters of biodiversity and fish migration routes. It is expected that after the pandemic is over, the government will focus on improving the environment.

\section{Acknowledgement}

We wish to thank all hosts and institutions who held online seminars and provided essential insights with many new perspectives. We also express our gratitude to Universitas Padjadjaran; this article is funded by RPDP Grants 2020, 1735/UN6.3.1/LT/2020. We sincerely appreciate Ahmad I. Anshory, Dannisa I. Handyman, Rahal Balazam, Joana Viviani, Agung Ramos, Egi Pamungkas, and Fahmi Ghiffari for their aids.

\section{REFERENCES}

Bates, A.E., Primack, R.B., Group, P.E.W., \& Duarte, C.M. (2021). Global COVID-19 lockdown highlights humans as both threats and custodians of the environment. Biological Conservation Biological Conservation, 1-19. https://doi.org/10.1016/j.biocon.2021.109175 
Canning-Clode, J., Sepúlveda, P., Almeida, S., \& Monteiro, J. (2020). Will COVID-19 Containment and Treatment Measures Drive Shifts in Marine Litter Pollution? Frontiers in Marine Science, 7(691), 1-4. https://doi.org/10.3389/fmars.2020.00691

Cordova, M.R., Nurhati, I.S., Riani, E., Nurhasanah, \& Iswari, M.Y. (2020). Unprecedented plastic-made personal protective equipment (PPE) debris in river outlets into Jakarta Bay during COVID-19 pandemic. Chemosphere, 268, 1-7. https://doi.org/10.1016/j.chemosphere.2020.129360

Corlett, R.T., Primack, R.B., Devictor, V., Maas, B., Goswami, V.R., Bates, A.E., \& Roth, R. (2020). Impacts of the coronavirus pandemic on biodiversity conservation. Biological Conservation, 246, 8-11. https://doi.org/10.1016/j.biocon.2020.108571

Erbe, C., Smith, J.N., Redfern, J.V., \& Peel, D. (2020). Editorial: Impacts of Shipping on Marine Fauna. Frontiers in Marine Science, 7 , 1-5. https://doi.org/10.3389/fmars.2020.00637

Fitriadi, C.A., Dhahiyat, Y., Purba, N.P., Harahap, S.A., \& Prihadi, D.J. (2017). Coral larvae spreading based on oceanographic condition in biawak islands, West Java, Indonesia. Biodiversitas, 18(2), 681-688. https://doi.org/10.13057/biodiv/d180234

Forster, P.M., Forster, H.I., Evans, M.J., Gidden, M.J., Jones, C.D., Keller, C.A., \& Turnock, S.T. (2020). Current and future global climate impacts resulting from COVID-19. Nature Climate Change, 10(10), 913-919. https://doi.org/10.1038/s41558-020-0883-0

Friedlingstein, P., Jones, M.W., O'Sullivan, M., Andrew, R.M., Hauck, J., Peters, G.P., \& Zaehle, S. (2019). Global carbon budget 2019. Earth System Science Data, 11(4), 1783-1838. https://doi.org/10.5194/essd-11-1783-2019

Garcés-Ordóñez, O., Espinosa Díaz, L.F., Pereira Cardoso, R., \& Costa Muniz, M. (2020). The impact of tourism on marine litter pollution on Santa Marta beaches, Colombian Caribbean. Marine Pollution Bulletin, 160, 111558. https://doi.org/https://doi.org/10.1016/j.marpolbul.2020.111558

Gaynor, K.M., Hojnowski, C.E., Carter, N.H., \& Brashares, J.S. (2018). The influence of human disturbance on wildlife nocturnality. Science, 360(6394), 1232-1235. https://doi.org/10.1126/science.aar7121

Gusviga, B.H., Subiyanto, Faizal, I., Yusri, S., Sari, S.K., \& Purba, N.P. (2021). Occurrence and Prediction of Coral Bleaching Based on Ocean Surface Temperature Anomalies and Global Warming in Indonesian Waters. IOP Conference Series: Earth and Environmental Science, 750(1), 1-13. https://doi.org/10.1088/1755-1315/750/1/012032

Halpern, B.S., Longo, C., Hardy, D., McLeod, K.L., Samhouri, J.F., Katona, S.K., \& Zeller, D. (2012). An index to assess the health and benefits of the global ocean. Nature, 488(7413), 615-620. https://doi.org/10.1038/nature11397

Ritchie, H., Ortiz-Ospina, E., Beltekian, E., Mathieu, E., Hasell, J., Macdonald, B., Giattino, C., Appel, C. Rodés-Guirao, L., \& Roser, M. (2020). Coronavirus Pandemic (COVID-19). Published online at OurWorldInData.org. https://ourworldindata.org/coronavirus

Ju, M.J., Oh, J., \& Choi, Y.H. (2021). Changes in air pollution levels after COVID-19 outbreak in Korea. Science of the Total Environment, 750, 1-9. https://doi.org/10.1016/j.scitotenv.2020.141521

Knopf, J.W. (2006). Doing a Literature Review. PS: Political Science \&amp; Politics, 39(1), 127-132. https://doi.org/ 10.1017/S1049096506060264

Laffoley, D., Baxter, J.M., Amon, D.J., Claudet, J., Hall-Spencer, J.M., Grorud-Colvert, K., \& Andersen, N.F. (2021). Evolving the narrative for protecting a rapidly changing ocean, post-COVID-19. Aquatic Conservation: Marine and Freshwater Ecosystems, 31(6), 1512-1534. https://doi.org/10.1002/aqc.3512

Le Quéré, C., Jackson, R.B., Jones, M.W., Smith, A.J.P., Abernethy, S., Andrew, R.M., \& Peters, G.P. (2020). Temporary reduction in daily global $\mathrm{CO} 2$ emissions during the COVID-19 forced confinement. Nature Climate Change, 10(7), 647-653. https://doi.org/10.1038/s41558-020-0797-x

March, D., Metcalfe, K., Tintoré, J., \& Godley, B.J. (2021). Tracking the global reduction of marine traffic during the COVID-19 pandemic. Nature Communications, 12(1), 1-29. https://doi.org/10.1038/s41467-021-22423-6

Nyström, M., Folke, C., \& Moberg, F. (2000). Coral reef disturbance and resilience in a human-dominated environment. Trends in Ecology and Evolution, 15(10), 413-417. https://doi.org/10.1016/S0169-5347(00)01948-0

Omrani, H., Omrani, B., Parmentier, B., \& Helbich, M. (2020). Spatio-temporal data on the air pollutant nitrogen dioxide derived from Sentinel satelitte for France. Data in Brief, 28, 1-8. https://doi.org/10.1016/j.dib.2019.105089

Partelow, S., von Wehrden, H., \& Horn, O. (2015). Pollution exposure on marine protected areas: A global assessment. Marine Pollution Bulletin, 100(1), 352-358. https://doi.org/https://doi.org/10.1016/j.marpolbul.2015.08.026

Patrício Silva, A.L., Prata, J.C., Walker, T.R., Duarte, A.C., Ouyang, W., Barcelò, D., \& Rocha-Santos, T. (2021). Increased plastic pollution due to COVID-19 pandemic: Challenges and recommendations. Chemical Engineering Journal, 405, 1-33. https://doi.org/10.1016/j.cej.2020.126683

Perillo, G.M.E., Botero, C.M., Milanes, C.B., Elliff, C.I., Cervantes, O., Zielinski, S., \& Glavovic, B.C. (2021). Integrated coastal zone management in the context of COVID-19. Ocean \& Coastal Management, 210, 105687. https://doi.org/10.1016/j.ocecoaman.2021.105687

Plagányi, É., Deng, R.A., Tonks, M., Murphy, N., Pascoe, S., Edgar, S., \& Dutra, L. (2021). Indirect Impacts of COVID-19 on a Tropical Lobster Fishery's Harvest Strategy and Supply Chain. Frontiers in Marine Science, 8, 1-14. https://doi.org/10.3389/fmars.2021.686065

Purba, N.P., Faizal, I., Mulyani, P., Prayogo, N., Prasetyo, T., \& Khan, A.M.A. (2019). Performance of lagriangan drifter oceanography coverage area (RHEA): second phase. International Journal of Oceans and Oceanography, 13(2), 353-361.

Rutz, C., Loretto, M.C., Bates, A.E., Davidson, S.C., Duarte, C.M., Jetz, W., \& Cagnacci, F. (2020). COVID-19 lockdown allows researchers to quantify the effects of human activity on wildlife. Nature Ecology and Evolution, 4(9), 1156-1159. https://doi.org/10.1038/s41559-020-1237-z

Salsabilla, A.V., Purba, N.P., Syamsudin, M.L., Faizal, I., \& Fitriadi, C.A. (2020). Mangrove Ecosystem Connectivity Based on Oceanographic System in Biawak Island, West Java, Indonesia. Asian Journal of Fisheries and Aquatic Research, 8(4), 1-9. https://doi.org/10.9734/ajfar/2020/v8i430143

Shokri, M.R., \& Mohammadi, M. (2021). Effects of recreational SCUBA diving on coral reefs with an emphasis on tourism suitability index and carrying capacity of reefs in Kish Island, the northern Persian Gulf. Regional Studies in Marine Science, 45, 101813. https://doi.org/https://doi.org/10.1016/j.rsma.2021.101813

Tobías, A., Carnerero, C., Reche, C., Massagué, J., Via, M., Minguillón, M.C., \& Querol, X. (2020). Changes in air quality during the lockdown in Barcelona (Spain) one month into the SARS-CoV-2 epidemic. Science of the Total Environment, 726, 1-4. https://doi.org/10.1016/j.scitotenv.2020.138540

Yang, W., Cai, F., Liu, J., Zhu, J., Qi, H., \& Liu, Z. (2021). Beach economy of a coastal tourist city in China: A case study of Xiamen. Ocean \& Coastal Management, 211, 105798. https://doi.org/https://doi.org/10.1016/j.ocecoaman.2021.105798

Zambrano-Monserrate, M.A., \& Ruano, M.A. (2019). Does environmental noise affect housing rental prices in developing countries? Evidence from Ecuador. Land Use Policy, 87, 104059. https://doi.org/https://doi.org/10.1016/j.landusepol.2019.104059

Zambrano-Monserrate, M.A., Ruano, M.A., \& Sanchez-Alcalde, L. (2020). Indirect effects of COVID-19 on the environment. Science of the Total Environment, 728, 1-4. https://doi.org/10.1016/j.scitotenv.2020.138813

Zangari, S., Hill, D.T., Charette, A.T., \& Mirowsky, J.E. (2020). Air quality changes in New York City during the COVID-19 pandemic. Science of the Total Environment, 742, 1-6, 140496. https://doi.org/10.1016/j.scitotenv.2020.140496

Zhang, Q., Jiang, X., Tong, D., Davis, S.J., Zhao, H., Geng, G., \& Guan, D. (2017). Transboundary health impacts of transported global air pollution and international trade. Nature, 543(7647), 705-709. https://doi.org/10.1038/nature21712

Zuhairoh, F., \& Rosadi, D. (2020). Real-time Forecasting of the COVID-19 Epidemic using the Richards Model in South Sulawesi, Indonesia. Indonesian Journal of Science \& Technology, 5(3), 456-462. https://doi.org/10.17509/ijost.v5i3.26139 